\title{
Wahania poziomów wody jezior w Polsce w latach 1956-2015 Water-level fluctuations in Polish lakes in the 1956-2015 period
}

\author{
Adam Choiński ${ }^{1}$ [D Jerzy Jańczak ${ }^{2}$ • Mariusz Ptak ${ }^{\mathbf{1}}$ (I) \\ ${ }^{1}$ Uniwersytet im. A. Mickiewicza, Zakład Hydrologii i Gospodarki Wodnej \\ ul. Krygowskiego 10, 61-680 Poznań \\ ${ }^{2}$ Uniwersytet Gdański, Instytut Geografii \\ ul. Bażyńskiego 4, 80-309 Gdańsk \\ choinski@amu.edu.pl•j.janczak@op.pl•ptakm@amu.edu.pl
}

Zarys treści. W pracy przedstawiono zmiany średnich rocznych poziomów wód 16 jezior w latach 1956-2015. Cechowały się one zróżnicowanymi amplitudami stanów wody, które wahały się od 26 cm (Jezioro Studzieniczne) do $132 \mathrm{~cm}$ (jezioro Roś). W analizowanym zbiorze odnotowano trzy sytuacje: wzrostu (pięć jezior), spadku (dwa jeziora) oraz braku wyraźnych tendencji zmian (dziewięć jezior) średnich rocznych stanów wody. Najszybszym tempem wzrostu poziomu wody charakteryzowało się jezioro Jamno (aż 6,3 cm·dek-1), a obniżenia - Jezioro Ełckie $\left(3,6 \mathrm{~cm} \cdot \mathrm{dek}^{-1}\right)$. Jeziora o różnym charakterze zmian poziomów wody, nie grupowały się w układzie regionalnym a różne kierunki zmian stanów wody, występowały nawet na jeziorach położonych w niewielkich odległościach od siebie. Uzyskane wyniki są zgodne z otrzymanymi z uprzednich badań z zakresu fluktuacji poziomu wody w jeziorach (z krótszych okresów badawczych), wskazując na kluczową rolę czynników lokalnych nad klimatycznymi.

Słowa kluczowe: jeziora, stany wody, tendencje, antropopresja, Polska.

\section{Wstęp}

Wahania poziomu wody należą do głównych czynników wpływających na funkcjonowanie jezior. Wielkość napełnienia mis jeziornych wodą ma istotne znaczenie dla przebiegu wielu procesów i zjawisk (Liu i inni, 2016; Mäemets i inni, 2018; Robertson i inni, 2018; Rybak i inni, 2018; Li i inni, 2019). Określona ilość wody w zbiorniku oraz stabilność zwierciadła wody są istotne z punktu widzenia działalności człowieka. Elementy te determinują wielkość i dostępność do zasobów wodnych jezior i decydują o możliwości ich wykorzystania przez różne dziedziny gospodarki np. przemysł, rolnictwo, turystykę. Wahania poziomu wody, ich skala, dynamika i tendencje zmian zależą od czynników naturalnych i antropogenicznych (Alifujiang i inni, 2017; Hinwood i inni, 2017; Yagbasan i inni, 2017; Babanazarova i inni, 2018; Doulgeris i Argyroudi, 2019). W odniesieniu do jezior w Polsce, tematyka związana z wahaniami poziomu wody była podejmowana przez wielu badaczy, na szerokim zbiorze obiektów, tj. od pojedynczych przypadków do kilkudziesięciu jezior. Prace te wskazują na złożoność tego procesu, a w odniesieniu do tendencji zmian, w zależności od przyjętego okresu analizy, pokazują zróżnicowany ich charakter i wskazują na różne przyczyny (Skibniewski, 1954; Pasławski, 1972; Jańczak i Choiński, 1993; Borowiak, 1997; Dąbrowski, 
2004; Chlost i Cieśliński, 2005; Machowski i inni, 2005; Piasecki i Marszelewski, 2014; Ptak i inni, 2017; Volchak i inni, 2017; Wrzesiński i Ptak, 2017; Wrzesiński i inni, 2018).

Celem pracy jest przedstawienie tendencji zmian stanów wody 16 jezior w Polsce w latach 1956-2015. Wyniki badań, jako pierwsze w tak długim ujęciu czasowym obejmujące kilkanaście jezior, w dobie intensywnych przeobrażeń środowiska przyrodniczego mają wskazać skalę i kierunek zmian stanów wody.

\section{Materiały i metody}

W pracy wykorzystano dane dla 16 jezior znajdujących w obrębie trzech głównych pojezierzy w Polsce, których lokalizację przedstawia rycina 1, a podstawowe parametry morfometryczne zestawiono $\mathrm{w}$ tabeli 1.

W pracy wykorzystano obserwacje stanów wody prowadzone przez Instytut Meteorologii i Gospodarki Wodnej - Państwowy Instytut Badawczy (IMiGW-PIB). Dane zestawione są w układzie roku hydrologicznego (XI-X). W przypadku trzech jezior (Sławskie, Biskupińskie, Gopło) wielolecie analizy obejmuje okres 1956-2014. Ponadto ze zbiorów IMGW-PIB pozyskano roczne sumy opadów dla dziewięciu stacji (ryc. 1).

Analizę trendów średnich rocznych stanów wody przeprowadzono za pomocą testu Manna-Kendalla. Opiera się on na określeniu nieparametrycznego współczynnika korelacji rangowej $\tau_{b}$-Kendalla dla danej serii danych oraz serii kolejnych kroków czasowych $t_{i}, i=1, \ldots, n$. Współczynnik $\tau_{b}$ określa siłę monotonicznego związku między dwiema zmiennymi. Jego wartość określa, o ile większy jest odsetek wszystkich możliwych par obserwacji, dla których kie-

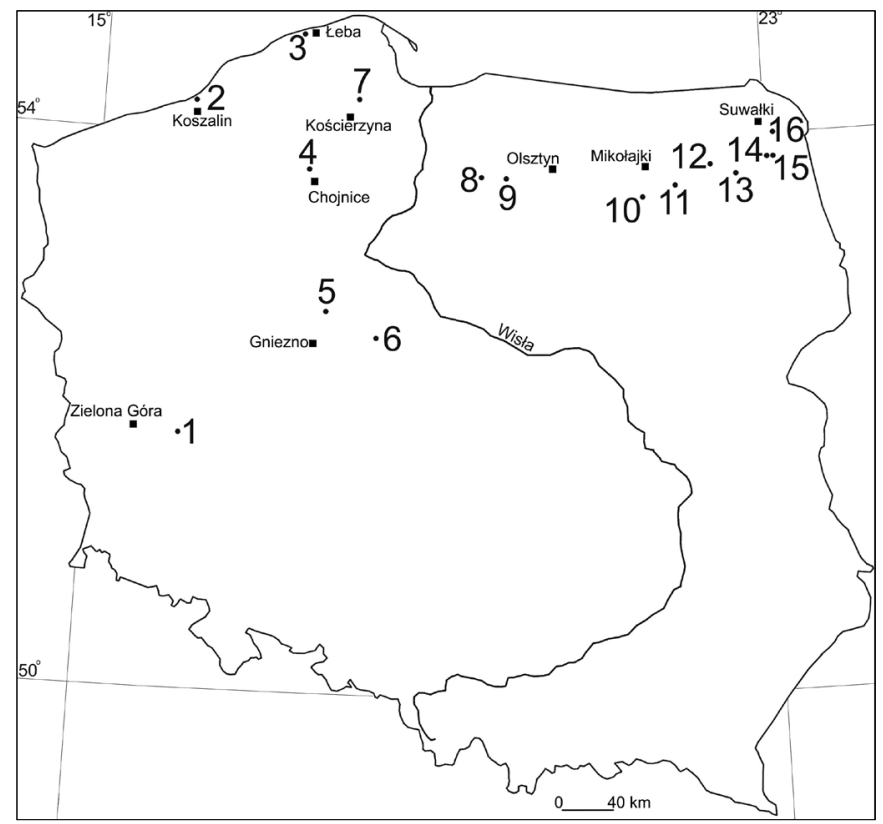

Ryc. 1. Lokalizacja obiektów badań (numeracja jezior zgodna z tabelą 1, miasta - stacje meteorologiczne) Locations of study objects (with numbering of lakes as in Table 1, plus cities as seats of meteorological stations) 
Tabela 1. Podstawowe parametry morfometryczne badanych jezior

Basic morphometric parameters of the lakes analysed

\begin{tabular}{|c|c|c|c|c|}
\hline & Jezioro & Powierzchnia (ha) & Objętość (mln m³) & Głębokość średnia (m) \\
\hline 1 & Sławskie & 823,0 & 42,66 & 5,2 \\
\hline 2 & Jamno & 2232,0 & 31,53 & 1,4 \\
\hline 3 & Łebsko & 7020,0 & 117,50 & 1,6 \\
\hline 4 & Charzykowskie & 1336,0 & 134,50 & 9,8 \\
\hline 5 & Biskupińskie & 107,0 & 6,38 & 5,5 \\
\hline 6 & Gopło & 2122,0 & 78,50 & 3,6 \\
\hline 7 & Ostrzyckie & 296,0 & 20,79 & 6,7 \\
\hline 8 & Jeziorak & 3153,0 & 141,59 & 4,1 \\
\hline 9 & Drwęckie & 780,0 & 50,14 & 5,7 \\
\hline 10 & Nidzkie & 1750,0 & 113,87 & 6,2 \\
\hline 11 & Roś & 1809,0 & 152,92 & 8,1 \\
\hline 12 & Ełckie & 385,0 & 57,42 & 15,0 \\
\hline 13 & Rajgrodzkie & 1499,0 & 142,62 & 9,4 \\
\hline 14 & Białe Augustowskie & 453,0 & 41,72 & 9,2 \\
\hline 15 & Studzieniczne & 244,0 & 22,07 & 8,7 \\
\hline 16 & Wigry & 2115,0 & 336,73 & 15,4 \\
\hline
\end{tabular}

Źródło/Source: Choiński (2006).

runek różnicy między nimi jest taki sam dla obu zmiennych, od odsetka par obserwacji, które takiej zgodności nie wykazują. Obliczany jest na podstawie statystyki $S$, która określa liczbę par obserwacji, które charakteryzują się zgodnymi kierunkami różnic dla obu analizowanych zmiennych.

\section{Wyniki i dyskusja}

Poniżej przedstawiono przebieg średnich rocznych poziomów wody analizowanych jezior(ryc. 2) oraz ich zwięzłą charakterystykę. Ponadto na rycinie 2 dodano roczne sumy opadów atmosferycznych.

Jez. Sławskie. Cechuje się małą amplitudą średnich rocznych poziomów wód, tj. $45 \mathrm{~cm}$. Występują kilkuletnie okresy o różnej długości średnich stanów rocznych wód względem stanu średniego (168 cm) z wielolecia, np. 1962-1975 i 1997-2005 poniżej, czy też 1976-1991 i 2006-2014 powyżej.

Jez. Jamno. Połączone przez Nurt Jamneński z morzem, a więc poddane jego wpływowi. Sytuacja ta uległa zmianie w roku 2013, kiedy to wybudowane zostały wrota przeciwsztormowe. Zanotowano dużą amplitudę średnich rocznych poziomów, tj. $52 \mathrm{~cm}$. Wyraźnie zaznaczają się dwa okresy, tj. do roku 1989 średnie stany roczne były poniżej stanu średniego $(528 \mathrm{~cm})$ z wielolecia, zaś po roku 1989 wyższe od niego. 
A 19
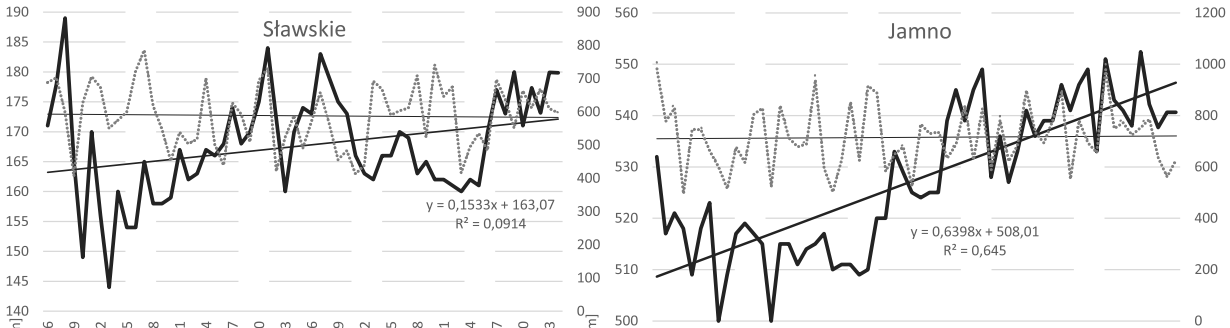

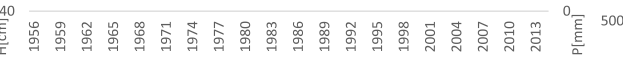

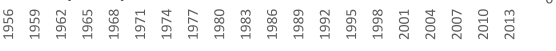
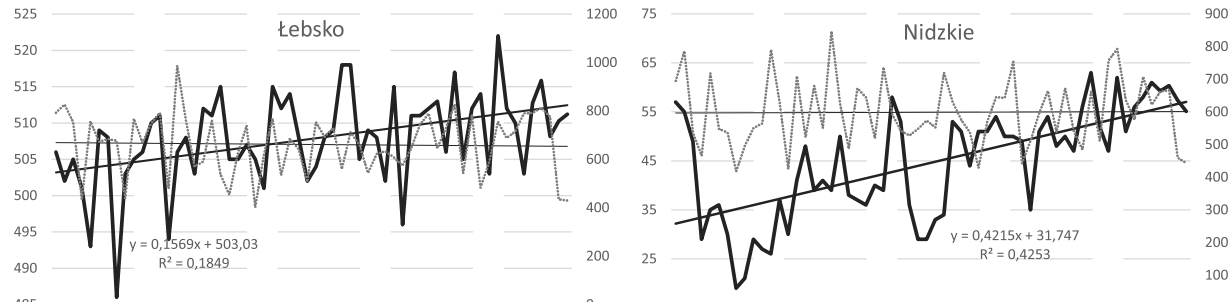

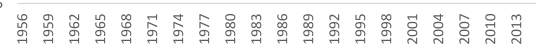

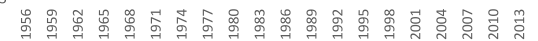

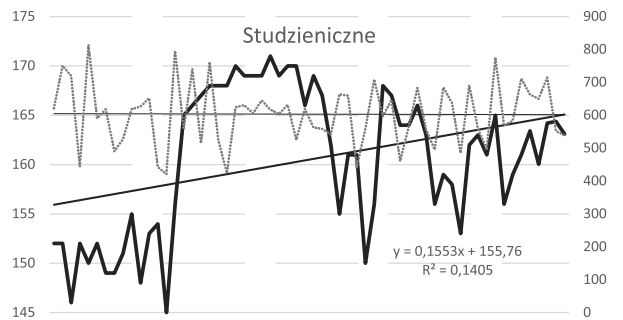

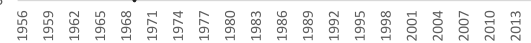

B

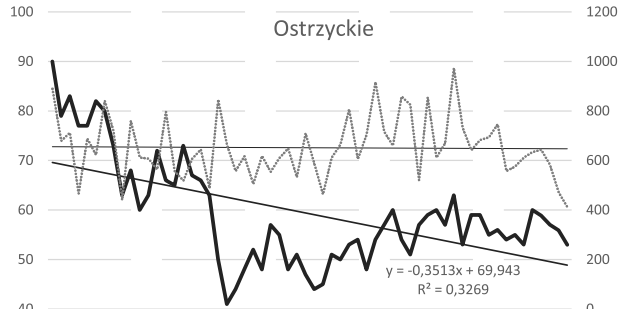

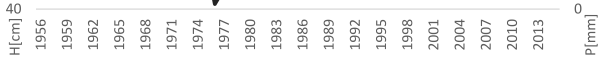

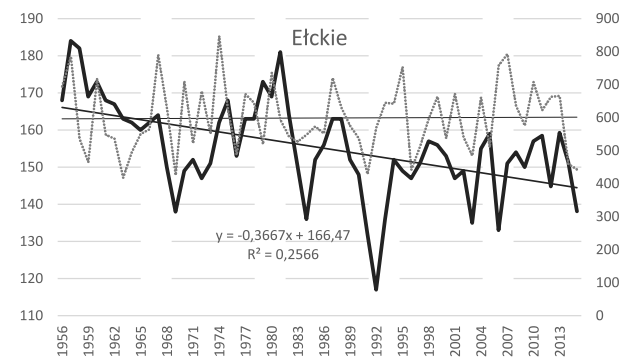

$\uparrow$
900

800

Ryc. 2. Przebieg średnich rocznych stanów wody analizowanych jezior (linia ciągła) oraz rocznych sum opadów atmosferycznych (linia przerywana) w latach 1956-2015. Objaśnienia: A) istotnie statystycznie $(p=0,05)$ tendencja wzrostowa, B) istotnie statystycznie $(p=0,05)$ tendencja spadkowa), C) brak istotnie statystycznie tendencji zmian

Courses of mean annual water levels in the lakes analysed (solid line), with totals for annual atmospheric precipitation (dotted line), 1956-2015 
C

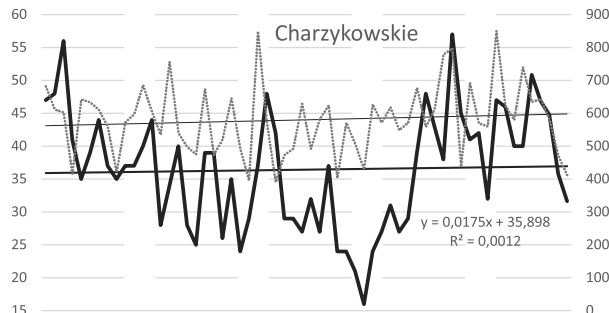

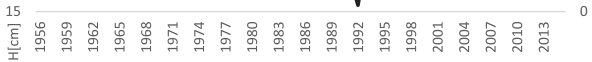

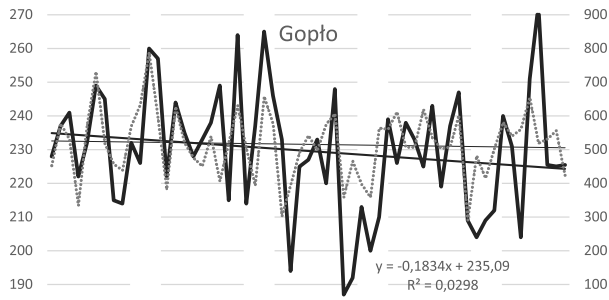

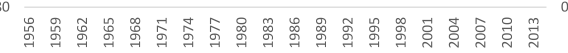

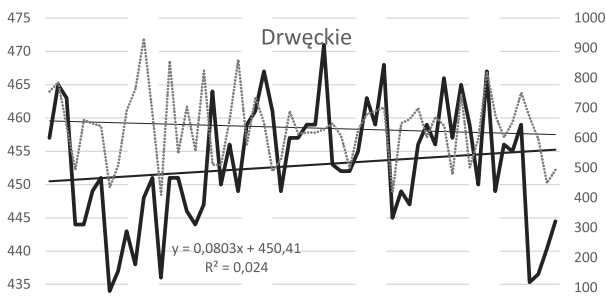

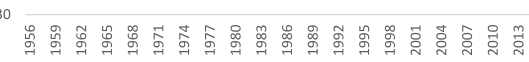

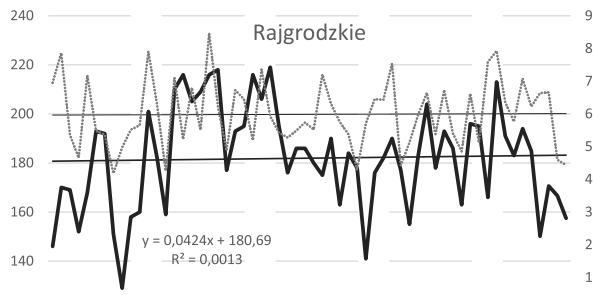

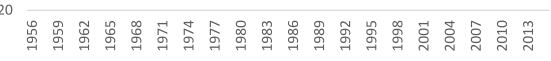

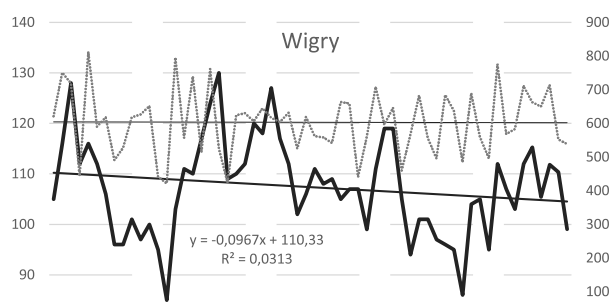

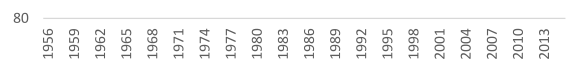

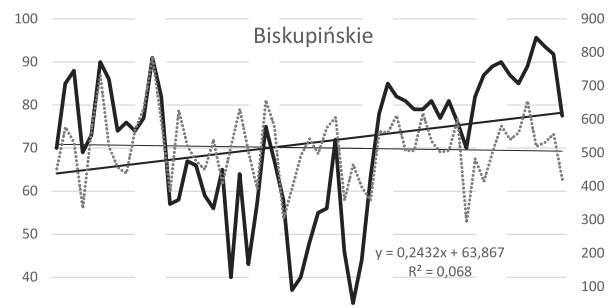

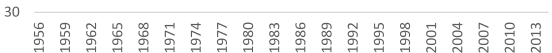

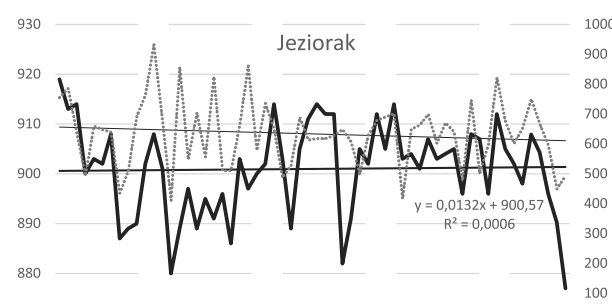

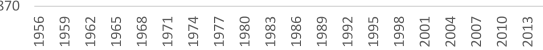

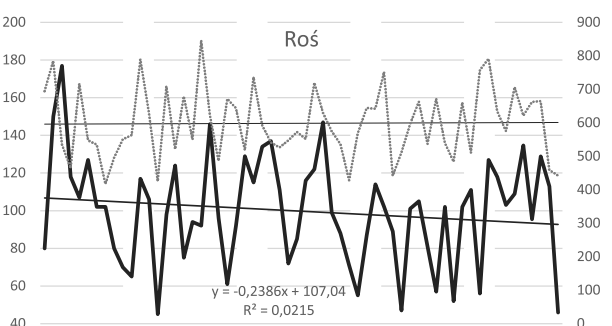

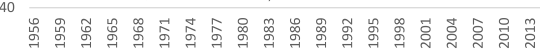

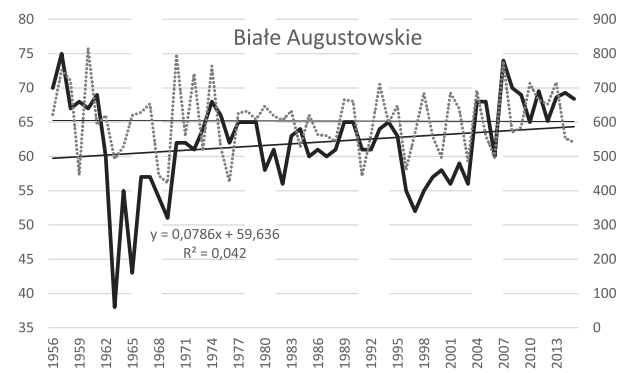


Jez. Łebsko. Podobnie jak jez. Jamno połączone jest z Bałtykiem. Zanotowano jedną z najmniejszych amplitud średnich rocznych poziomów wód, tj. $36 \mathrm{~cm}$. Trudno wydzielić okresy o wyraźnych tendencjach wzrostu lub spadku poziomu wód, bowiem średnie roczne poziomy oscylują z dużą zmiennością wokół wartości średniej $(508 \mathrm{~cm})$. Niemniej po roku 1980 częściej pojawiają się średnie poziomy roczne powyżej wartości średniej. W niektórych latach widać bardzo wyraźne analogie stanów Łebska i Jamna (np. rok 1960, 1963, 1969, 2006, 2007), ale wśród nich są również lata z widocznym złagodzeniem skali zmian stanów wód Łebska w stosunku do Jamna.

Jez. Nidzkie. Amplituda średnich rocznych poziomów wód w analizowanym wieloleciu wyniosła $44 \mathrm{~cm}$. Od 1956 do 1963 r. był notowano gwałtowny spadek średnich poziomów rocznych, przy czym w latach 1959-1970 utrzymywały się one poniżej średniej z wielolecia (45 cm). Od 1964 r. występował permanentny wzrost średnich poziomów rocznych jednak z kilkuletnimi okresami poniżej wartości średniej z wielolecia (1972-1974, 1976-1980, 1983-1987).

Jez. Studzieniczne. Spośród wszystkich analizowanych jezior posiada najmniejszą amplitudę średnich rocznych poziomów, tj. jedynie $26 \mathrm{~cm}$. W latach 1969-1971 nastąpił wzrost średniego poziomu wody o blisko $20 \mathrm{~cm}$, spowodowany ingerencją człowieka. Zarówno jednak przed, jak i po podpiętrzeniu, poziom wody był wyjątkowo wyrównany.

Jez. Ostrzyckie. Amplituda średnich rocznych poziomów w latach 1956-2015 osiągnęła $49 \mathrm{~cm}$. W przebiegu średnich poziomów rocznych można wydzielić trzy okresy: 1956-1976 - spadek, 1977-2002 - wzrost i 2003-2015 - spadek.

Jez. Ełckie. Od 1970 r. poziom został podwyższony o około $100 \mathrm{~cm}$. Na wykresie uwzględniono dodanie tej wielkości dla lat 1956-1969, co pozwoliło na sprowadzenie wahań poziomu wód do wspólnego mianownika. Tym samym naturalna amplituda średnich rocznych poziomów wód jest znaczna, bowiem wynosi $67 \mathrm{~cm}$. Najdłuższe okresy, gdy średni poziom wód był powyżej średniego poziomu z wielolecia $(155 \mathrm{~cm})$, to lata 1956-1967 i 1977-1982. W całym analizowanym wieloleciu wyraźnie zaznacza się konsekwentny spadek średnich rocznych poziomów.

Jez. Charzykowskie. Niewielka amplituda średnich rocznych poziomów wód, tj. $41 \mathrm{~cm}$. Od 1958 do 1978 r. występowała wyraźna tendencja obniżania średnich rocznych poziomów wody, przy czym w latach 1968-1978 najczęściej te stany wody notowane były poniżej wartości średniej $(36 \mathrm{~cm}$ ) z lat 1956-2015. W roku 1981 nastąpiło znaczne podniesienie średniego stanu rocznego aby do roku 1992 zmniejszać się z niewielkimi oscylacjami. Następnie do 2002 r. miał miejsce ich wzrost, aby ponownie z małymi wahnięciami zmniejszać się do 2015 r.

Jez. Biskupińskie. Duża amplituda średnich rocznych poziomów wód, tj. 62 cm. Wyraźnie zaznaczają się 3 okresy, tj. do 1968 r. i po 1992 r. średnie roczne stany wody powyżej stanu średniego z wielolecia $(71 \mathrm{~cm}$ ), zaś w latach 1968-1992 z reguły poniżej jego. Ostatni okres to sukcesywny wzrost poziomu wody. 
Jez. Gopło. Jedna z najwyższych amplitud średnich rocznych poziomów wód spośród analizowanych jezior, tj. $86 \mathrm{~cm}$. Sytuacja taka spowodowana jest dynamiką zmian przepływów dużej rzeki, przepływającej przez Gopło jaką jest Noteć. Występują roczne lub kilkuletnie okresy średnich rocznych stanów wody poniżej lub powyżej wartości średniej (229cm).

Jez. Jeziorak. Mała amplituda średnich rocznych poziomów wahań wód, tj. 42 cm. Do 1976 r. obserwowane było obniżania poziomu wody przy jednoczesnym długim występowaniu średnich stanów rocznych poniżej średniego z wielolecia (901cm). Od 1976 do 2015 r. notowana jest przewaga stanów powyżej średniej z badanego okresu.

Jez. Drwęckie. Niewielka amplituda średnich rocznych poziomów wód, tj. $37 \mathrm{~cm}$. W latach 1959-1974 poziom przez cały ten okres układał się poniżej poziomu średniego z wielolecia (453cm). Od 1975 r. ma miejsce przewaga w występowania stanów powyżej niego.

Jez. Roś. Spośród analizowanych jezior posiada zdecydowanie największą amplitudę średnich rocznych poziomów wód. Osiąga ona aż $132 \mathrm{~cm}$. Po gwałtownym wzroście poziomu od 1956 do 1958 r. następował stopniowy spadek trwający do 1966 r. Następnie przez cały czas występowały wielokierunkowe oscylacje, przy czym do roku 1988 częściej były ponad średnim poziomem z wielolecia $(100 \mathrm{~cm})$, zaś od roku 1989 poniżej niego. W ostatniej dekadzie ponownie średnie roczne poziomy wody układały się powyższej średniej z wielolecia. Na poziom wody tego jeziora niewątpliwy wpływ ma jaz usytuowany na Kanale Jeglińskim.

Jez. Rajgrodzkie. Zaobserwowano wyjątkowo duże wahania średnich rocznych poziomów wód, tj. $90 \mathrm{~cm}$. W znacznym stopniu może to być spowodowane regulacją, bowiem jezioro jest podpiętrzone jazem. W przebiegu wahań średnich rocznych poziomów wód można wyróżnić trzy okresy: 1956-1975 - wzrost, 1976-1992 - spadek oraz 1993-2015 wzrost. Najdłużej poniżej średniego poziomu z wielolecia $(182 \mathrm{~cm})$ zalegały średnie roczne poziomy w okresie 1983-1998.

Jez. Białe. Niewielka amplituda średnich rocznych poziomów wód, tj. $37 \mathrm{~cm}$. Wyraźne dwa okresy średnich rocznych poziomów wód poniżej średniego z wielolecia, to lata 1962-1970 i 1995-2003, mniej wyraźne powyżej to lata 1956-1961 oraz 2004-2015.

Jez. Wigry. Amplituda wahań średnich rocznych poziomów wód wynosi $45 \mathrm{~cm}$. Wyraźnie zaznacza się kilka kilkuletnich okresów średnich stanów rocznych występujących na przemian powyżej lub poniżej średniego stanu wód z wielolecia $(107 \mathrm{~cm})$.

Powyższe wyniki są zobrazowaniem dużego zróżnicowania przebiegu średnich rocznych stanów wody w rozpatrywanym wieloleciu. W zbiorze analizowanych przypadków odnotowano trzy sytuacje: wzrost, spadek (istotne statystycznie na poziomie $p=0,05$ ) oraz brak tendencji zmian. Do pierwszej grupy należą jeziora: Sławskie, Jamno, Łebsko, Nidzkie i Studzieniczne, do drugiej: Ostrzyckie i Ełckie a do ostatniej pozostałe jeziora: Charzykowskie, Jeziorak, Rajgrodzkie, Biskupińskie, Drwęckie, Białe, Gopło, Roś i Wigry.

Spośród jezior w których odnotowano istotnie statystycznie wzrost poziomu wody najszybsze tempo miało miejsce w przypadku Jamna i wyniosło aż 6,3 cm $\cdot$ dek $^{-1}$. Z kolei 
najszybciej obniżenie poziomu wody miało miejsce w przypadku Jeziora Ełckiego, gdzie średni roczny stan wody jest aktualnie niższy w stosunku do początku analizy aż o blisko $22 \mathrm{~cm}$. W badaniach przebiegu stanów wody jezior, a zwłaszcza przy porównywaniu tendencji, istotne znaczenie ma długość rozpatrywanego okresu. Najbogatsze wnioski można oczywiście wyprowadzić z długich ciągów obserwacyjnych. Niestety, w przypadku polskich jezior znacznym utrudnieniem dla badaczy są częste przenoszenia lub likwidacje posterunków pomiarowych. W Atlasie jezior Polski (Jańczak, 1996, 1997, 1999) rozpatrywane są wahania poziomów wody 108 jezior. Okresy ich obserwacji były zróżnicowane, od ponad 100 lat do minimum 20. Wśród tych jezior są wszystkie rozpatrywane w niniejszym artykule, jednak ciąg obserwacji kończył się dla nich w 1995 r. W okresie 1956-1995, tylko cztery jeziora miały taką samą tendencję zmian jak za okres 1956-2012/13. Są to jeziora: Nidzkie - tendencja dodatnia, Ełckie i Ostrzyckie - tendencja ujemna i Jeziorak - brak tendencji. W pozostałych 12 jeziorach, tendencje były inne lub ich nie było. W wielu przypadkach widoczne są następujące po sobie okresy wzrostu i spadku stanów wody. Przyczyny tych wahań były złożone. J. Jańczak i inni (1994) zauważyli, że zmiany te są związane m.in. z kilkuletnimi suszami i okresami z ponadnormatywnymi opadami na które nakładają się uwarunkowania lokalne. Przykładowo dla jezior Charzykowskie i Biskupińskie na przestrzeni analizowanego wielolecia nie wykazano istotnych zmian poziomu wody, lecz dla krótszych okresów zmiany te były znaczące. Dotyczy to m.in. wzrostu poziomu wody od lat 90., który miał miejsce po głębokiej suszy na początku dekady. Ponadto należy podkreślić, że na fluktuacje zmian warunków klimatycznych, poszczególne jeziora reagowały indywidualnie - wyraźnie, słabo lub wcale. Dobrym przykładem tego stwierdzania są m.in. jeziora Ełckie i Rajgrodzkie (znajdujące się w odległości ok. 20 km względem siebie), gdzie sumy opadów (jako wejściowy element w bilansie wodnym) miały w obu przypadkach zróżnicowany charakter w stosunku do przebiegu stanów wody.

Wahania stanów wody w jeziorach są wypadkową czynników naturalnych i antropogenicznych, decydujących o warunkach hydrologicznych w zlewni. O. Bonacci i inni (2015) analizując wahania poziomu wody w jeziorze Dojran (Macedonia) stwierdzili, że nie jest łatwo określić jakie czynniki (naturalne lub antropogeniczne) mają decydujący wpływ na ten proces. Wniosek ten ma charakter bardzo uniwersalny w czasach znacznych przekształceń środowiska naturalnego. W odniesieniu do analizowanych w pracy zmian poziomów wody w zdecydowanej większości wpływ na przebieg stanów wody miały czynniki lokalne niż klimatyczne, co potwierdza m.in. brak spójnych regionalnych wydzieleń tendencji zmian. Jest to sytuacja odmienna, niż np. w odniesieniu do reżimu termicznego (Ptak i inni, 2018) czy lodowego (Choiński i inni, 2015) jezior w Polsce, gdzie widoczne są wyraźne podobieństwa cech powyższych, uzależnionych w głównej mierze od warunków klimatycznych. E. Bajkiewicz-Grabowska (2001), na podstawie przeanalizowanych prac podkreśla, że w przebiegu stanów wód jeziornych w Polsce w układzie wieloletnim, warunki klimatyczne nie pełniły pierwszoplanowej roli. Autorka nie stwierdziła istotnych statystycznie relacji pomiędzy opadami a stanami wód 21 jezior w Polsce północno-wschodniej.

Badania tendencji zmian średnich rocznych stanów wody 32. jezior w Polsce wykazywały ich dużą zmienność przestrzenną i czasową (Wrzesiński i Ptak, 2016). W przypadku 7 jezior były one rosnące, a w 7 malejące, z kolei w pozostałych przypadkach zmiany nie były istotne statystycznie. Nasilenie aktywności człowieka jest wymieniane m.in. przez A. Górniaka i K. Piekarskiego (2002), jako ważny czynnik w modyfikowaniu naturalnego cyklu hydrologicznego w polskich jeziorach. Dynamiczny rozwój społeczny na obszarze Polski, 
notowany jest na XVIII i XIX w. Wówczas to podejmowano wielkie prace melioracyjne a uzyskane tereny adoptowane były dla celów rolniczych lub osadniczych. W przypadku jezior skutkowało to obniżeniem poziomu wody (Kaniecki, 1997) lub ich całkowitym zanikiem (Ptak i inni, 2013; Ptak 2015a). Szczegółową analizę zmian poziomu wody w wyniku aktywności człowieka dla jeziora Gopło przeprowadzili Dorożyński i Skowron (2002) - tabela 2.

Jezioro Gopło zawsze charakteryzowało się dużymi wahaniami poziomu wody (Jańczak i inni, 2002). Jednak od czasu zbudowania jazu w Pakości, amplitudy maksymalne często przekraczały $1 \mathrm{~m}$, a w niektórych latach sięgały nawet 1,5 m. Przy średniej głębokości jeziora wynoszącej około 3,5 m, jest to wyjątkowo dużo. Tak duże wahania sprzyjają zwiększeniu zanieczyszczenia Gopła biogenami, wypłukiwanymi z przesuszonych osadów. Poza tym, wzrasta wówczas niekorzystne oddziaływanie dna czynnego.

Trwające dziesięciolecia prace melioracyjne spowodowały kurczenie zasobów wodnych. Priorytetową stała się konieczność retencjonowania wody w zlewniach, redukując w ten sposób skrajne sytuacje hydrologiczne - zarówno susze jak i powodzie. W odniesieniu do jezior bezpośrednia ingerencja w ich reżim hydrologiczny dotyczy m.in. zabudowy hydrotechnicznej na wypływie, co stwarza możliwość regulowania stanów a tym samym zasobów zmagazynowanych w nich wody. Przykładowo jedynie w przypadku województwa wielkopolskiego, przewidziane jest podpiętrzenie 48 naturalnych jezior o pojemności 33,008 mln $\mathrm{m}^{3}$ (www.wzmiuw.pl). M. Sojka i inni (2010) zauważają, że jednym z podstawowych kierunków zabudowy zlewni w której występują jeziora, mając na uwadze pokrycie potrzeb wodnych jej użytkowników, jest ich podpiętrzenie. Zabiegi takie są prostsze, tańsze i mniej inwazyjne dla środowiska niż budowa nowych sztucznych zbiorników retencyjnych, która prowadzi do wielkoskalowych przeobrażeń. Rolę urządzeń hydrotechnicznych w retencji wód jeziornych, dobrze obrazuje przypadek Jeziora Powidzkiego. B. Nowak i M. Ptak (2018) opisują sytuację gdzie wyremontowana w 2010 r. zastawka, umiejscowiona na wypływie z jeziora, wespół z wysokimi opadami w tym okresie, przyczyniła się do przedłużenia wystąpienia wysokich stanów wody a w konsekwencji również do wzrostu zasobów wodnych. Pomimo niewątpliwych korzyści dla zwiększenia zasobów wodnych, regulacja naturalnych jezior nie zawsze jest rozwiązaniem racjonalnym dla lokalnej społeczności. S. Murat-Błażejewska i inni, (2008) odnoszą się do przypadku Jeziora Niepruszewskiego,

Tabela 2. Zmiany zwierciadła wody jeziora Gopło Changes in the water level of Lake Gopło

\begin{tabular}{|c|l|c|}
\hline Rok & \multicolumn{1}{|c|}{ Działania } & $\begin{array}{c}\text { Poziom zwier- } \\
\text { ciadła wody } \\
\text { (m n.p.m.) }\end{array}$ \\
\hline 1772 & Przed pierwszymi pracami regulacyjnymi & 80,20 \\
1775 & Zakończenie budowy Kanału Bydgoskiego & 79,70 \\
1811 & Pomiary niwelacyjne wykonane przez Surowieckiego & 79,80 \\
1860 & Prace drenażowe w zlewni górnej Noteci & 78,30 \\
$1879-1975$ & Kanalizacja Górnej Noteci w latach 1870-1878 & 77,00 \\
1912 & Pomiary batymetryczne jeziora Gopło przeprowadzone przez Schütze & 77,02 \\
1923 & Pomiary batymetryczne jeziora Gopło przeprowadzone przez Sperczyńskiego & 77,02 \\
od 1975 & Regulacja odpływu na jazie w Pakości & 76,82 \\
\hline
\end{tabular}

Źródło: Dorożyński i Skowron (2002), zmodyfikowane / Source: Dorożyński i Skowron (2002), as in part modified. 
gdzie istniejący jaz był wykorzystywany do nawadniania rolniczego a następnie dla potrzeb gospodarki rybackiej. W 2002 r., w wyniku presji właścicieli gruntów otaczających jezioro, funkcjonowanie jazu zostało ograniczone. Podobną sytuację odnotowano w przypadku jeziora Wierzchowo (Ptak, 2015b). Jaz na Gwdzie, usytuowany na odpływie, dawał możliwość regulowania poziomu wody w tym jeziorze, ale z uwagi m.in. na podtopienia sąsiednich terenów odstąpiono od jego podpiętrzania.

Spośród analizowanych w pracy 16 jezior, aż 9 było regulowanych (jazy, zastawki na wypływie lub zabudowa hydrotechniczna poniżej jeziora). Podjęcie takich działań miato na celu optymalne ich wykorzystanie do celów gospodarczych (transport, nawodnienia, energetyka). Przykładowo Jezioro Ostrzyckie wchodzące w skład większego zespołu jezior (raduńsko-ostrzyckich), jest istotnym elementem dla rozwoju regionu. E. Okulanis (1981) który dokonał szczegółowego opracowania tego akwenu stwierdził, że cały zespół powyższych jezior dzięki możliwości sztucznego regulowania przepływu stanowi naturalny zbiornik retencyjny, wywierający wpływ na wyrównywanie przepływów rzeki Raduni. Fakt ten był istotny dla pracy elektrowni wodnych usytuowanych na tej rzece oraz innej infrastruktury gospodarczej zlokalizowanej na przepływach międzyjeziornych. Odnosząc się do zmienności stanów wody ten sam autor stwierdza, że wykorzystanie jezior do powyższych celów spowodowało zachwianie równowagi dynamicznej. Z kolei sam przebieg wahań ma charakter lokalny. Przykładowo Jezioro Białe i Studzieniczne są istotną częścią Kanału Augustowskiego - drogi wodnej eksploatowanej już ponad 180 lat. Połączenie Wielkich Jezior Mazurskich systemem kanałów (w skład których wchodzi m.in. Nidzkie, Roś) miało w pierwotnym założeniu stanowić drogę wodną, m.in. dla spławiania drewna z Puszczy Piskiej, a pierwsze sztuczne połączenia wykonano już w drugiej połowie XVIII w. (Dąbrowski, 2013). Ustabilizowanie poziomu wody a tym samym stworzenie możliwości żeglugowych pomiędzy jeziorami sprawiło, że od dziesięcioleci region ten jest chętnie odwiedzanym przez osoby uprawiające sporty wodne, co przynosi wymierne korzyści ekonomiczne. Z kolei Jezioro Rajgrodzkie jest zbiornikiem retencyjnym, wykorzystywanym jako źródło nawodnień torfowiska Kuwasy (Chrzanowski, 1995).

Powyższe przykłady wskazują na szeroki zakres adaptacji jezior, w których sztucznie zostały uregulowane wahania poziomu wody. W perspektywie obserwowanych zmian klimatycznych, istotne będzie posiadanie możliwie bardziej szczegółowej wiedzy o możliwościach prowadzenia odpowiedniej gospodarki wodnej w odniesieniu do naturalnych jezior, które stanowią łatwo dostępne rezerwuary wody.

\section{Podsumowanie}

W pracy przedstawiono wahania stanów wody 16 jezior w okresie ostatnich sześćdziesięciu lat. Uzyskane wyniki wskazują na bardzo złożony charakter tego zagadnienia. Odnotowano wszystkie trzy możliwe przypadki, tj. wzrost poziomu wody, spadek a także żadnej tendencji zmian. Co ważne obserwacje te nie grupowały się w układzie regionalnym a różne kierunki zmian stanów wody, występowały nawet na jeziorach położonych w niewielkich odległościach od siebie. Uzyskane wyniki są zgodne z otrzymanymi z wcześniejszych badań z zakresu zmian poziomu wody w jeziorach (z krótszych okresów badawczych), wskazując na kluczową rolę czynników lokalnych nad klimatycznymi. Informacje te mogą być kluczowe dla zarządzania zasobami wodnymi w kontekście obserwowanych zmian kli- 
matycznych. Przy zarządzaniu zasobami wodnymi jezior, należy mieć na uwadze zarówno zasoby ilościowe jak i jakościowe. Dla jakości wód jeziornych, najlepiej jest, gdy poziom wody jest wysoki i mało zmienny.

Ryciny i tabele, pod którymi nie zamieszczono źródła, są opracowaniami własnymi autorów artykułu.

\section{Piśmiennictwo}

Alifujiang Y., Abuduwaili J., Ma L., Samat A., Groll M., 2017, System dynamics modeling of water level variations of lake Issyk-Kul, Kyrgyzstan, Water, 9, 12, 989.

Babanazarova O.V., Sidelev S.I., Zhdanova S.M., Litvinov A.S., Ovseenko A.S., Korovkina K.P., 2018, Water Level in a Shallow Highly Eutrophic Lake: Development Factor by Macrophyte or Phytoplankton Type: Case Study of Lake Nero, Yaroslavl Oblast, Water Resources, 45, 6, s. 897-907.

Bajkiewicz-Grabowska E., 2001, Trends in water level changes in the lakes of North-eastern Poland, Limnological Review, 1, s. 1-14.

Bonacci O., Popovska C., Geshovska V., 2015, Analysis of transboundary Dojran Lake mean annual water level changes, Environmental Earth Sciences. 73, 7, s. 3177-3185.

Borowiak D., 1997, Wahania poziomów jezior Polski w latach 1961-95, ZHiGW IGF UAM, Wydawnictwo Homini, Poznań-Bydgoszcz.

Choiński A., 2006, Katalog jezior Polski, Wydawnictwo Naukowe UAM, Poznań.

Choiński A., Ptak M., Skowron R., Strzelczak A., 2015, Changes in ice phenology on polish lakes from 1961-2010 related to location and morphometry, Limnologica, 53, s. 42-49.

Chlost I., Cieśliński R., 2005, Change of level of waters Lake Łebsko, Limnological Review, 5, s. 17-26

Chrzanowski S., 1995, Retencyjność torfowiska i jej wykorzystanie w systemie nawodnień podsiqkowych na przykładzie obiektu Kuwasy i Zbójna Popiołki, Raport końcowy za okres badań 1993-1995, IMUZ, Falenty.

Dąbrowski M., 2013, Uwarunkowania naturalne i antropogeniczne obiegu wody w Systemie Wielkich Jezior Mazurskich, IMGW-PIB, Warszawa.

Doulgeris C., Argyroudi A., 2019, Contribution to decision-making on establishing the maximum water level for Lake Vegoritida, Lakes and Reservoirs: Research and Management, 24, 1, s. 24-36.

Dorożyński R., Skowron R., 2002, Changes of the basin of Lake Gopło caused by melioration work in the 18th and 19th centuries, Limnological Review, 2, s. 93-102.

Górniak A., Piekarski K., 2002, Seasonal and Multiannual Changes of Water Levels in Lakes of Northeastern Poland, Polish Journal of Environmental Studies, 11, 4, s. 349-354.

Hinwood J., Aoki S.-I., Okabe T., 2017, Effect of Regulation of the Inlet Channel on Tides and Water Levels in Lake Hamana, Japan, Coastal Engineering Journal, 59, 3, 1750016.

Jańczak J. (red.), 1996, 1997, 1999. Atlas jezior Polski, t. 1-3, IMGW, Bogucki Wydawnictwo Naukowe, Poznań.

Jańczak J., Choiński A., 1993, Zmiany wahań poziomu wody jezior w latach 1956-1985, [w:] I. Dynowska (red.), Przemiany stosunków wodnych w Polsce w wyniku procesów naturalnych i antropogenicznych, Uniwersytet Jagielloński, Kraków, s. 98-107.

Jańczak J., Kowalik A., Sziwa R., 1994, Reakcja stanów wody jezior dorzecza Odry na suszę lat 1989-1992, Wiadomości IMGW, 17, 2, s. 117-124. 
Jańczak J., Lossow K., Kowalik A., Sziwa R., 2002, Zanieczyszczenie i możliwości odnowy jeziora Gopło, Materiały Badawcze IMGW, Seria: Gospodarka Wodna i Ochrona Wód, 21, IMGW, Warszawa.

Kaniecki A., 1997, The influence of anthropopressure on water relations in the Wielkopolska Lowland, Geographia Polonica, 68, s. 78-80.

Li C., Yang Y., Wang Z., Yang L., Zhang D., Zhou L., 2019, The relationship between seasonal water level fluctuation and habitat availability for wintering waterbirds at Shengjin Lake, China, Bird Conservation International, 29, 1, s.100-114.

Liu X., Teubner K., Chen Y., 2016, Water quality characteristics of Poyang Lake, China, in response to changes in the water level, Hydrology Research, 47, s. 238-248.

Machowski R., Ruman M., Rzętała M., 2005, Water stage fluctuations in selected anthropogenic water reservoirs in the upper part of the Odra catchment, Limnological Review, 5, s. 145-153.

Mäemets H., Laugaste R., Palmik K., Haldna M., 2018, Response of primary producers to water level fluctuations of Lake Peipsi, Proceedings of the Estonian Academy of Sciences, 67, 3, s. 231-245.

Murat-Błażejewska S, Zbierska J, Ławniczak A, Kanclerz J, Kupiec J, Sojka M, 2008, Eksploatacja urzqdzeń wodnych a zasoby wodne zlewni nizinnej, Acta Scientiarum Polonorum. Architectura, 526, 7, 2, s. 13-22.

Nowak B., Ptak M., 2018, Effect of a water dam on Lake Powidzkie and its vicinity, Bulletin of Geography. Physical Geography Series, 15, 1, s. 5-13.

Okulanis E, 1981, Studium limnologiczne jezior raduńsko-ostrzyckich, Gdanskie Towarzystwo Naukowe, Gdańsk.

Pasławski Z., 1972, Wieloletnie wahania i tendencje zmian poziomu wód jezior odpływowych w Polsce Północnej, Przegląd Geofizyczny, 17, 3-4, s. 249-259.

Piasecki A., Marszelewski W., 2014, Dynamics and consequences of water level fluctuations of selected lakes in the catchment of the Ostrowo-Gopło Channel, Limnological Review, 14, 4, s. 187-194.

Ptak M., 2015a, Wpływ antropopresji na zmienność stanów wody jeziora Wierzchowo w latach 1976-2009, Zeszyty Naukowe Uniwersytetu Zielonogórskiego, Inżynieria Środowiska, 159, 39, s. $5-14$.

Ptak M., 2015b, Odtworzenie nieistniejqcych jezior jako element zwiększania retencji leśnej i pozaprodukcyjnych funkcji lasu, Sylwan, 159, 5, s. 427-434.

Ptak M., Choiński A., Strzelczak A., Targosz A., 2013, Disappearance of Lake Jelenino since the end of the XVIII century as an effect of anthropogenic transformations of the natural environment, Polish Journal of Environmental Studies, 22, 1, s. 191-196.

Ptak M., Wrzesiński D., Choiński A., 2017, Long-term changes in the hydrological regime of high mountain lake Morskie Oko (Tatra Mountains, Central Europe), Journal of Hydrology and Hydromechanics, 65, 2, s. 146-153.

Ptak M., Sojka M., Choiński A., Nowak B., 2018, Effect of environmental conditions and morphometric parameters on surface water temperature in Polish lakes, Water, 10, 580.

Robertson D.M., Juckem P.F., Dantoin E.D., Winslow L.A., 2018, Effects of water level and climate on the hydrodynamics and water quality of Anvil Lake, Wisconsin, a shallow seepage lake, Lake and Reservoir Management, 34, 3, s. 211-231.

Rybak M., Joniak T., Gąbka M., 2018, Environmental implications of water level fluctuations in deep chara-lake in light of hydrochemistry and water transparency in phytolittoral zone, International Multidisciplinary Scientific GeoConference Surveying Geology and Mining Ecology Management, SGEM, 18, 3.1, s. 267-274.

Skibniewski L., 1954, Wahania poziomów zwierciadła wody większych jezior Pojezierza Pomorskiego i Mazurskiego, Przegląd Meteorologiczny, 7, 3-4. 
Sojka M., Murat-Błażejewska S., Kanclerz J., 2010, Ocena możliwości retencjonowania wody w jeziorach zlewni Strugi Dormowskiej, Infrastruktura i ekologia terenów wiejskich, 8, s. 5-13.

Volchak A., Choiński A., Kirviel I., Parfomuk S., 2017, Spectral analysis of water level fluctuations in Belarusian and Polish lakes, Bulletin of Geography. Physical Geography Series, 12, s. 51-58.

Wrzesiński D., Ptak M., 2016, Water level changes in Polish lakes during 1976-2010, Journal of Geographical Sciences, 26, 1, s. 83-101.

Wrzesiński D., Ptak M., 2017, An investigation of water level fluctuations in Polish lakes in various phases of the winter North Atlantic Oscillation, Geology, Geophysis and Environment, 43, 2, s. 151-163.

Wrzesiński D., Ptak M., Plewa K., 2018, Effect of the North Atlantic Oscillation on water level fluctuations in lakes of Northern Poland, Geographia Polonica, 91, 2, s. 243-259.

Yagbasan O., Yazicigil H., Demir V., 2017, Impacts of climatic variables on water-level variations in two shallow Eastern Mediterranean lakes, Environmental Earth Sciences, 76, 16, 575.

\section{Summary}

Water-level fluctuations are among the primary factors determining the functioning of lakes. The volume to which lake basins are filled with water is of major importance to the courses of many processes and phenomena. A particular amount of water in a lake, and water-table stability, are also important from the point of view of human activity, as these elements help determine the quantity and accessibility of the water resources lakes have to offer, and therefore the possibilities for them to be used by different branches of the economy, e.g. industry, agriculture or tourism. The work detailed here is thus a presentation of trends as regards water-level fluctuations in 16 lakes in Poland, over the period 1956-2015. The study results, obtained for the first time in relation to such a long time scale and extending to around a dozen lakes, aim to point to the scale and direction of water-level fluctuations in times of the intensive transformation of the natural environment. They were obtained by reference to water-level observations made by the Institute of Meteorology and Water Management - National Research Institute (IMiGW-PIB). Specifically, data referring to the (November-October) hydrological year were analysed for trends as regards mean annual water levels using the Mann-Kendall test. Results point to major variability in the courses noted for these levels over the analysed multiannual period. Nevertheless, three overall situations could be designated from within the group of cases analysed, i.e. increase, decrease or lack of a trend. The first group includes Lakes Sławskie, Jamno, Łebsko, Nidzkie, and Studzieniczne (where increases were statistically significant at $p=0.05$ ); the second, Lakes Ostrzyckie and Ełckie (decreases significant at $p=0.05$ ); and the last group all remaining lakes, i.e. Charzykowskie, Jeziorak and Rajgrodzkie, Biskupińskie, Drwęckie and Białe, Gopło, Roś, and Wigry. It was, however, noted that in many cases analysed periods of alternating increase and decrease in water level were to be observed. The causes of such fluctuations were complex, but inter alia reflected droughts of several years' duration, periods featuring higher-than-average precipitation, and local conditions. In general, water-level fluctuations in lakes result from natural and anthropogenic factors determining the hydrological conditions in catchments. And in the context of the lakes considered here, the courses of water-level fluctuations were mostly a reflection of local, rather than wider climatic conditions - a fact i.a. illustrated by the lack of cohesive regio- 
nal designations. The situation is different from that of, for example, the thermal or ice regimes of Polish lakes, in relation to which observed similarities in properties are seen to be determined mainly by climatic factors. Information of this kind may be of key importance to the (quantitative and qualitative) management of water resources in the context of the climate change being observed currently. 